\title{
On Improving Endurance of Unmanned Ground Vehicles: The ATRV-Jr Case Study
}

\author{
S. Ioannou ${ }^{1}$, K. Dalamagkidis ${ }^{2}$, K. P. Valavanis ${ }^{2}$, E. K. Stefanakos ${ }^{1}$ and P. H. Wiley ${ }^{1}$
}

\begin{abstract}
Unmanned ground vehicles (UGVs) have strict payload limitations, limited free space affecting power supply availability (number of batteries, size and volume) that impact onboard available energy resulting in limited endurance and operational range. This limitation is exacerbated by the addition of extra sensors and other related equipment needed for diverse applications. The ATRV-Jr UGV is considered as a testbed to identify causes of reduced runtime and operational range offering a detailed analysis of component power consumption. A comparative study between Lead Acid, Lithium and Fuel Cell technologies allows for power supply enhancement via i) an optimum design with weight, volume, runtime and rechargeability being major restrictions and concerns, and, ii) the use of lower power sensors and processors without affecting vehicle functionality and operability.
\end{abstract}

\section{INTRODUCTION}

C urrent UGV power sources are almost exclusively rechargeable lead-acid and $\mathrm{NiCad}$ batteries due to the fact that both technologies are mature and well understood, as well as cheaper compared to more recent technologies such as lithium batteries and fuel cells.

Recent concerns about energy and environmental problems and advances in material and manufacturing engineering, have enabled a wider commercial product selection in lithium batteries and fuel cells. For example, Proton Exchange Membrane Fuel Cells (PEMFC) have already been tested and used in Autonomous Underwater Vehicles (AUVs) [1]-[4] and mobile robots [5], [6]. As stated in [4], Direct Methanol Fuel Cells (DMFC) is a better choice for mobile robots, but wide power range units are commercially unavailable.

UGV power requirements are mostly determined by the manufacturer for a specific vehicle configuration, ignoring the impact of possible upgrades, 'off-the-self' add on sensors and other custom made accessories, such as multiple cameras, Inertial Measurement Unit (IMU), GPS, compass, laser rangefinders and sonar sensors in addition to computer controlled processors and cooling fans.

Given that a UGV has limited power availability, endurance and range are drastically affected by the on-board sensor suite and other peripherals. This dependence and restriction

Manuscript received February 1, 2006. This work was supported in part by the U.S. Army Research Office (ARO) under Grant W91-11NF-06-0069.

${ }^{1}$ Clean Energy Research Center (CERC), Department of EE (E-mail: cerc@eng.usf.edu)

${ }^{2}$ Center for Robot Assisted Search and Rescue (CRASAR), Department of CSE (E-mail: kvalavan@cse.usf.edu).

University of South Florida, 4202 East Fowler Avenue, ENB 118, Tampa, FL 33620 becomes even worse if and when the UGV needs serve as the 'base station' and take off/landing platform for small/miniature unmanned electrical vertical take off and landing (VTOL) vehicles that require recharging upon landing on the UGV to continue their mission.

Considering restrictions and limitations on runtime and endurance as a function of a custom made vehicle and take off/landing platform (UGV-VTOL vehicle system), this paper provides a comparative study of currently available battery and fuel cell technologies (with respect to their application on UGVs), followed by a justified recommendation to improve UGV endurance and runtime based on a priori set mission requirements. Recommendations for power supply include energy requirements for the aforementioned landing platform as well (although details are offered in a separate paper) [7].

It is true that for most UGV outdoors applications, payload needs, sensor suite utilization and energy requirements are apriori unpredictable. This makes proper sizing of energy storage devices a rather difficult task. However, for this research, considering trade-offs, as well as a wide range of outdoors applications related to search and rescue, surveillance, mapping, demining threat identification and patrolling, requirements for energy storage devices have been sized for a maximum travel distance of $25 \mathrm{Km}, 12$ hours of continuous operation and two recharges of the electric unmanned VTOL. Since improved endurance is of high priority set requirements are coupled with recommendations for more efficient sensors.

\section{BATTERY AND Fuel CELl STATE OF THE ART}

State of the art battery technology profiles are summarized in Table I, with nickel cadmium (NiCad) being the oldest technology. Its high life cycle, low internal resistance, and high load current characteristics make it an attractive choice for power tools, two way radios and biomedical instruments. Reusable alkaline batteries on the other hand are very cheap, but their high internal resistance limits their use to only very low current applications. Furthermore, despite low energy density, low price makes sealed lead acid (SLA) batteries attractive for applications where volume and weight is not a problem. Lithium ion batteries are the most expensive. With high energy density and cell voltage, lithium technology is an attractive choice for electronic devices where dimensions and weight are critical, such as consumer electronics. Furthermore, material technology advancements have enabled manufacturing of scaled up lithium batteries for satellite and 
electric vehicle applications as shown in Table II.

TABLE I

BATTERY TECHNOLOGY PROFILE (FROM [8], [9])

\begin{tabular}{|l|c|c|c|c|c|}
\hline & NiCad & NiMH & SLA & $\begin{array}{l}\text { Li- } \\
\text { Ion }\end{array}$ & $\begin{array}{l}\text { Reusable } \\
\text { Alkaline }\end{array}$ \\
\hline $\begin{array}{l}\text { Energy Density } \\
(\mathrm{Wh} / \mathrm{Kg})\end{array}$ & $40-60$ & $60-80$ & 30 & 100 & 80 (initial) \\
\hline $\begin{array}{l}\text { Internal } \\
\begin{array}{l}\text { Resistance } \\
(\mathrm{m} \Omega)\end{array}\end{array}$ & $\begin{array}{c}100- \\
300\end{array}$ & $\begin{array}{c}200- \\
800\end{array}$ & $<100$ & $\begin{array}{c}300- \\
500\end{array}$ & $200-2000$ \\
\hline Cycle Life & 1500 & 500 & $\begin{array}{c}200- \\
300\end{array}$ & $\begin{array}{c}500- \\
1000\end{array}$ & 10000 \\
\hline $\begin{array}{l}\text { Cell Voltage } \\
(\mathrm{V})\end{array}$ & 1.2 & 1.2 & 2 & 3.6 & 1.5 \\
\hline Load Current & $>2 \mathrm{C}$ & $0.5-1 \mathrm{C}$ & $0.2 \mathrm{C}$ & $1 \mathrm{C}$ & $0.2 \mathrm{C}$ \\
\hline $\begin{array}{l}\text { Operating } \\
\text { Temperature } \\
\left({ }^{\circ} \mathrm{C}\right)\end{array}$ & -40 to & -20 to & -20 to \\
+60 & +60 & $\begin{array}{c}-20 \text { to } \\
+60\end{array}$ & 0 to 65 \\
\hline Cost (USD) & $\$ 50$ & $\$ 70$ & $\$ 25$ & $\$ 100$ & $\$ 5$ \\
\hline $\begin{array}{l}\text { In Commercial } \\
\text { Use Since }\end{array}$ & 1950 & 1990 & 1970 & 1991 & 1992 \\
\hline
\end{tabular}

TABLE II

LITHIUM ION FOR ELECTRIC VEHICLE APPLICATIONS (FROM [14])

\begin{tabular}{|c|c|c|c|c|c|c|}
\hline Model & $\begin{array}{c}\text { Rated } \\
\text { Capacity } \\
\text { (Ah) }\end{array}$ & $\begin{array}{c}\text { Nominal } \\
\text { Voltage } \\
\text { (V) }\end{array}$ & \multicolumn{2}{|c|}{$\begin{array}{c}\text { Dimensions (mm) } \\
\text { W - L - H }\end{array}$} & $\begin{array}{c}\text { Weight } \\
\text { (Kg) }\end{array}$ \\
\hline LIM40-3 & 40 & 11.4 & 180 & 227 & 160 & 9 \\
\hline LIM40-7 & 40 & 26.6 & 180 & 451 & 160 & 17 \\
\hline LIM80-4 & 80 & 15.2 & 180 & 463 & 160 & 18 \\
\hline LIM80-7 & 80 & 26.6 & 180 & 766 & 160 & 30 \\
\hline
\end{tabular}

Secondary batteries have limited runtime that is directly proportional to energy density and inversely proportional to load characteristics, with recharging process requiring several hours. On the other hand, fuel cells shown in Table III may provide constant power for as long as oxygen and hydrogen are provided, with refueling requiring only a few minutes. However, hydrogen storage [15] is a complex process, and the hydrogen container is bulky. Finally fuel cells have high operating temperatures.

TABLE III

Fuel CELL TECHNOLOGY PROFILE (FROM [16])

\begin{tabular}{|l|c|c|c|c|c|c|}
\hline & PAFC & AFC & MCFC & SOFC & SPFC & DMFC \\
\hline Operating & $150-$ & $60-$ & $600-$ & $900-$ & $50-$ & $50-100$ \\
Temperature & 210 & 100 & 700 & 1000 & 100 & \\
$\left({ }^{\circ} \mathrm{C}\right)$ & & & & & & \\
\hline Power & $0.2-$ & $0.2-$ & $0.1-0.2$ & $0.24-$ & $0.35-$ & $0.04-$ \\
Density & 0.25 & 0.3 & & 0.3 & 0.6 & 0.23 \\
$(\mathrm{~W} / \mathrm{cm} 2)$ & & & & & & \\
\hline Projected & 40,00 & 10,00 & 40,000 & 40,00 & 40,00 & 10,000 \\
Life (hrs) & 0 & 0 & & 0 & 0 & \\
\hline Projected & 1000 & 200 & 1000 & 1500 & 200 & 200 \\
cost & & & & & & \\
$($ US\$/KW) & & & & & & \\
\hline
\end{tabular}

Batteries and fuel cells have limited power densities that limit fast response to a demand greater than average load power demands. This power quality problem may cause the computer to reset and motors to stall. A common solution to this problem is to oversize the battery at the expense of cost, weight and size. Unlike batteries and fuel cells, super capacitors (Table IV at the end of the paper) have very high power but very low energy densities that limit their use as a primary power source. However, a high energy density device (battery) may be connected in parallel to a high power device (super capacitor) to form a hybrid power supply combination. Research reported in [10], [11] and [17]-[19] has shown that a hybrid configuration is a more effective solution than over sizing a battery.

\section{CURRENT ATRV-JR ENDURANCE}

Based on manufacturer specifications the $A T R V-J r$ is $0.62 \mathrm{~m}$ wide, $0.77 \mathrm{~m}$ long, $0.55 \mathrm{~m}$ high, it weighs $50 \mathrm{Kg}$ and has a payload capability of $25 \mathrm{Kg}$. It is powered by two 12 volt leadacid batteries, 360 Watt-hours (720W-hr total), 12Kg (27lbs) and 343 inch $^{3}\left(4 \mathrm{dm}^{3}\right)$ each, connected in series. Runtime is terrain dependent and it is limited between 3-5 hours. However, due to custom modifications made to the vehicle under consideration (on-board computer platform and installation of additional external sensors for a wider range of applications) actual runtime has been reduced to about 1 hour!

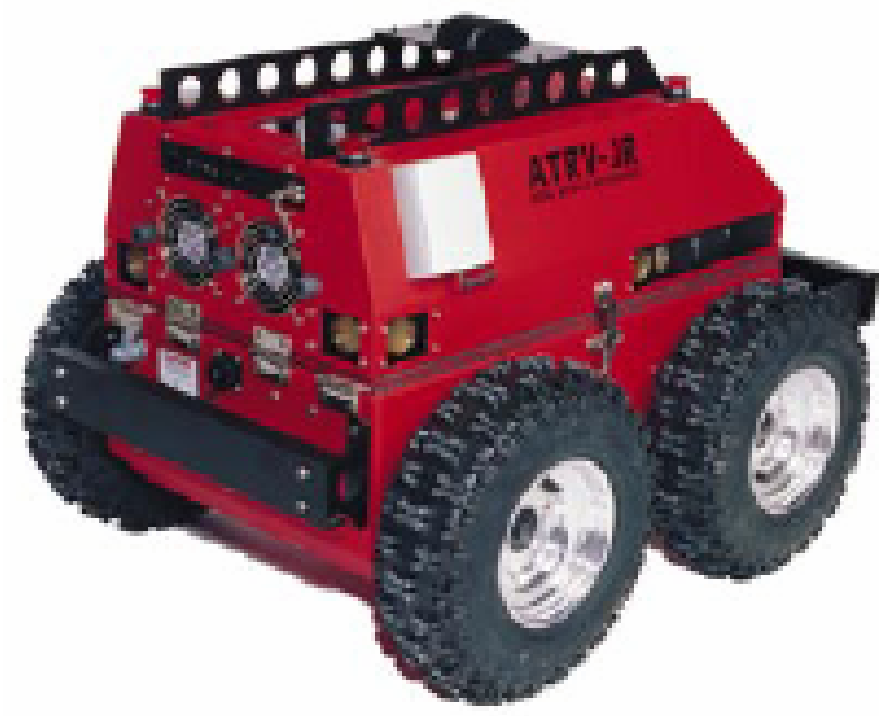

Figure 1: Photo of the ATRV-Jr.

Without upgrades and added sensors, only the computer and vehicle motors are connected directly to the batteries. The Pentium $3800 \mathrm{MHz}$ computer with $30 \mathrm{~W}$ power demand at $24 \mathrm{~V}$ requires $1.25 \mathrm{~A}$, whereas the two motors require $5.44 \mathrm{~A}$ total (2.72A each). At load current of $6.69 \mathrm{~A}$, runtime is approximately 4 hours. Terrain dependency, smaller loads like cooling fans and 17 sonar sensors and losses result in runtime variation between 3 and 5 hours.

With upgrades and added sensors, 2 DC/DC converters and a $300 \mathrm{~W}$ ATX power supply are connected directly to the batteries to provide regulated voltages to power the sensors and the on-board computer (see Figure 2). Theoretically, the total converter power of $230.28 \mathrm{~W}$ at $24 \mathrm{~V}$ requires $9.6 \mathrm{~A}$, whereas the $300 \mathrm{~W}$ ATX power supply at $24 \mathrm{~V}$ requires $12.5 \mathrm{~A}$. At full load with all upgrades the load current would be $28 \mathrm{~A}$, and runtime would be decreased to 1.1 hours. However, a 
more analytical analysis shows that the Pentium 4, 3GHz processor requires $120 \mathrm{~W}$. Considering 60-70\% ATX power supply efficiency (built for desktops), the computer power consumption is about 156-162W. Furthermore, the total sensor power demand is only $86 \mathrm{~W}$ and could be raised to $100 \mathrm{~W}$ when considering $80 \%$ efficiency for the DC/DC converters and voltage regulators. This analysis gives a full load current of $17 \mathrm{~A}$ and runtime of 1.8 hours. All runtimes are calculated based on advertised 30 AH battery capacity.

Further detailed analysis has shown that currently the $A T R V$ $J r$ is powered by two $12 \mathrm{~V}$ lead-acid batteries with $33 \mathrm{AH}$ capacity at 20 hour discharge rate. To meet the $24 \mathrm{~V}$ operating voltage, the batteries are connected in series. Figure 3 illustrates the performance of the DCS-33H lead acid battery pack. At 20 hour discharge rate and discharge current of $1.65 \mathrm{~A}$, the battery pack has a capacity of $33 \mathrm{AH}$, whereas at one hour discharge rate and current of 19.7A the capacity drops to 19.7AH. Therefore, for a load current of 17A, discharge time is estimated at 1.2 hours and battery pack capacity is estimated at 20.4AH. Discharge current follows a linear relationship with capacity of the order $y=33.8-0.78 x$ and an exponential relationship with discharge time or runtime of the order $y=27.86\left(e^{-0.21 x}\right)$, see Figure 3. Therefore, reduced endurance performance of the $A T R V-J r$ under consideration was expected since load demand increased and as a result battery pack capacity and runtime decreased.

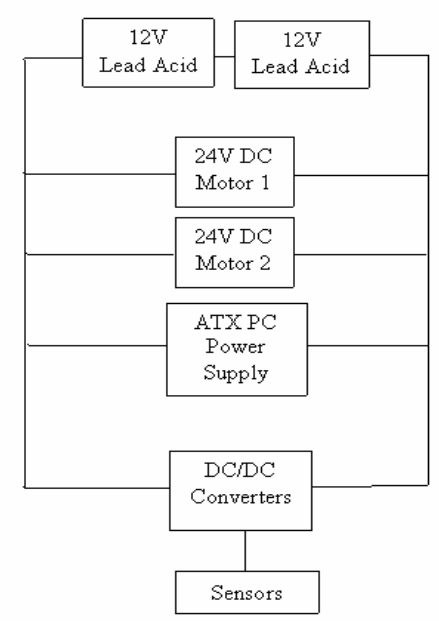

Figure 2: Connections of the ATRV-Jr. Subsystems

The next section describes how the ATRV-Jr endurance may be enhanced even after designing and installing a take off/landing platform on top of it.

\section{UGV WITH TAKE OFF/LANDING PLATFORM LOWER POWER DEMAND, HigHER EFFICIENCY \& ENDURANCE}

As previously stated, requirements for energy storage devices have been sized for a maximum travel distance of $25 \mathrm{Km}, 12$ hours of continuous operation and two recharges of the electric unmanned VTOL.

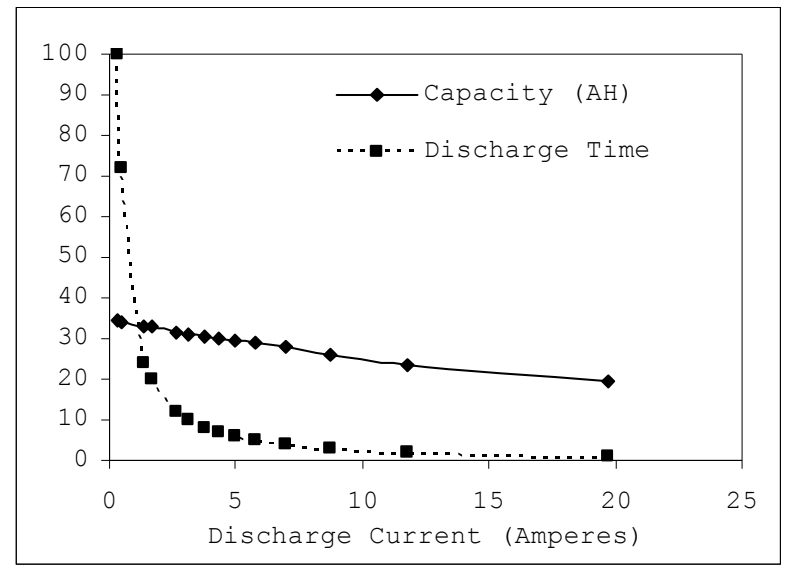

Figure 3: Capacity (AH) and Discharge Time (Hours) Versus Discharge Current of Deep Cycle DCS-33H Lead Acid Batteries.

\section{Sensors \& Processing platform}

The current configuration of the $A T R V-J r$ with all sensors and power consumption requirements is presented in Table $\mathrm{V}$. The cameras alone consume up to $60 \mathrm{~W}$ out of the total consumption that is about $86 \mathrm{~W}$ !

As a first step to save energy, lower power sensors that offer the same capabilities with the existing ones are proposed as shown in Table VI, resulting in a significant reduction of power consumption that is about $75 \%$ corresponding to total power consumption of $21.9 \mathrm{~W}$ !

TABLE V

ATRV-JR CURRENT SENSORS

\begin{tabular}{|l|c|c|}
\hline Sensor Type & Voltage (V) & Power (W) \\
\hline Laser & 24 & 17.5 \\
\hline Fans (two) & 24 & 4.08 \\
\hline IMU & 12 & 3 \\
\hline Fan & 12 & 0.24 \\
\hline Sony Cameras (two) & 12 & 60 \\
\hline GPS & 9 & 0.6 \\
\hline Compass Total Consumption & 0.1 \\
\hline \multicolumn{2}{|c|}{} \\
\hline
\end{tabular}

TABLE VI

PROPOSED LOW POWER SENSORS

\begin{tabular}{|l|c|}
\hline Sensor Type & Power (W) \\
\hline Sony CCTV Camera - FCB (2) & 3.6 \\
\hline GPS-Carmin 18, 12 channel & 0.3 \\
\hline IMU - ETB & 0.5 \\
\hline Range Finder - SICK LMS-200-30106 & 17.5 \\
\hline Total Consumption & $\mathbf{2 1 . 9}$ \\
\hline
\end{tabular}

TABLE VII

PROCESSOR POWER CONSUMPTION (FROM [20]-[22])

\begin{tabular}{|l|c|c|}
\hline Processor Type & \multicolumn{2}{|c|}{ Power Demand (Watts) } \\
\hline & Idle State & Max Work Load \\
\hline Intel Pentium D 820 & 50 & 134.3 \\
\hline Intel Pentium 4 & 49 & 130.6 \\
\hline Intel Pentium M & 20.8 at $1.2 \mathrm{GHz}$ & 30 at $2.66 \mathrm{GHz}$ \\
\hline Intel Pentium $0.13 \mu \mathrm{m}$ & 30 at $1.6 \mathrm{GHz}$ & 76 at $3.2 \mathrm{GHz}$ \\
\hline Intel Pentium $90 \mathrm{~nm}$ & 30 at $1.866 \mathrm{GHz}$ & 88 at $3.33 \mathrm{GHz}$ \\
\hline AMD Athlon64, +3500 & 11.6 & 45.6 \\
\hline
\end{tabular}

As a second step, a comparative study of processor power consumption (for processors with $3 \mathrm{GHz}$ clock speed) shown 
in Table VII has revealed that the Pentium 4 processor with $3 \mathrm{GHz}$ clock speed consumes as much power as the two motors of the $A T R V$-Jr.

As observed in Table VII, the two Intel processors tested at 3 to $3.4 \mathrm{GHz}$ for maximum work load required power consumption of $131 \mathrm{~W}$ and $134 \mathrm{~W}$ respectively [20]. At idle state, Intel's speed step technology reduces the power consumption to $50 \mathrm{~W}$ by running the processor at $2.865 \mathrm{GHz}$. On the other hand the AMD processor at the same clock speeds consumes only $45.6 \mathrm{~W}$ under load and $11.6 \mathrm{~W}$ in idle mode. Furthermore, the Pentium M processor, specifically designed for mobile applications, has a maximum power consumption of $30 \mathrm{~W}$ at $2.66 \mathrm{GHz}$ clock speed, whereas at idle state the demand drops to $21 \mathrm{~W}$ by reducing the clock speed to $1.2 \mathrm{GHz}$.

The recommendation is to use a Pentium M 2.66 GHz and Compact Flash memory for storage. Compact Flash memory has the advantage of low power consumption, vibration resistance and plug in plug out capability. The latter feature makes programming of the $A T R V-J r$ easier and allows for storage of various mission scenarios in different memory modules, loading them as needed.

With the proposed configuration, maximum power demand of the processor including that of the proposed sensors is about $60 \mathrm{~W}$. It is also proposed to use the MI-ATX power supply with $80-90 \%$ efficiency (as opposed to the currently used desktop power supply with $60-70 \%$ efficiency), thus reducing the total estimated power consumption from $300 \mathrm{~W}$ to $70 \mathrm{~W}$ only.

In summary, following the stated recommendation for low power sensors, processor and power supply, results in decreasing the total full load power demand (including the motors), by $44.6 \%$ (from $408 \mathrm{~W}$ to $226 \mathrm{~W}$ ) and as a consequence runtime increases from 1.1 to 2.5 hours.

\section{Powering the ATRV-JR with lithium batteries}

The $A T R V-J r$ speed is $1 \mathrm{~m} / \mathrm{s}$ that is translated to $3.6 \mathrm{Km} / \mathrm{hr}$. The additional load of the take off/landing platform on top of the UGV has an accurately estimated power consumption of $25 \mathrm{~W}$ and VTOL recharging need of $200 \mathrm{Wh}$. Total required energy to achieve the set goal is estimated to be $1957 \mathrm{Wh}$ resulting in a required battery capacity of $85 \mathrm{Ah}$.

Comparing available energy storage devices as shown in Tables I to IV, it is observed that scaled up lithium technology batteries require $1 / 3$ the weight and $1 / 2$ the volume of lead acid batteries [8], [9], [23] and [24]. Therefore, for the same available volume, lithium batteries double the runtime and reduce weight from 24 to $8 \mathrm{Kg}$. By comparing lead acid and $\mathrm{Li}-$ Ion batteries in Table VIII (shown at the end of the paper), it is seen that $\mathrm{Li}$-Ion VL45E cells produced by Saft provide 3 times the energy density of lead acid batteries. Furthermore, the use of the high energy cells VL45E and VL27M instead of the high power cells VL30P and VL20P, provide the total mission energy demand with approximately one third less weight and volume. For 10 hour continuous operation, use of
VL45E cells requires a matrix of 14 cells at a weight of $15 \mathrm{Kg}$, whereas the use of the VL30P cells requires a matrix of 21 cells at a weight of $23.1 \mathrm{Kg}$.

Alternative designs based only on lithium technology batteries, as shown in Table VIII, may reduce the battery pack weight to $15 \mathrm{Kg}$ and still achieve a runtime of 10 hours. However, lithium batteries may not be the best available choice; current commercial scale up lithium batteries require at least 2 to 3 hours to be charged. For this reason fuel cells offer a better choice for powering the $A T R V$, due to their easy refueling process. This recommendation is justifiable since as stated in [1] the Urashima AUV had an increase in travel distance of $65.4 \%$ when powered by a fuel cell system instead of lithium ion batteries.

\section{Using a combination of lithium batteries and a fuel cell}

DMFC (Direct Methanol Fuel Cell) has a relatively low operating temperature of $120^{\circ} \mathrm{C}$ compared to other $\mathrm{FC}$ systems, making it the best and safest choice. However, commercially available DMFC such as the $250 \mathrm{~W}$ iGen system provided by Idatech does not meet the required power demand. As such, based on commercial availability, the next best choice is the PEMFC (Proton Exchange Membrane Fuel Cell).

Two other available options are the Ballard's Nexa [25] and Hydrogenic's H2X-82 [26] stacks, with weight and volume of $13 \mathrm{Kg}, 46.2 \mathrm{dm}^{3}$ and $7 \mathrm{Kg}, 5.8 \mathrm{dm}^{3}$, respectively. But both are not suitable because of weight and volume restrictions; the dimensions and weight listed are for the stacks only. The complete system including the hydrogen storage tank, air compressor and valves is too big and heavy for the ATRV-Jr.

TABLE IX

\begin{tabular}{|l|c|c|c|}
\hline \multicolumn{1}{|c}{ ALTERNATIVE SOLUTION (DMFC AND BATTERY). } \\
\hline $\begin{array}{c}\text { Typen } \\
\text { DMFC by } \\
\text { Idatech }\end{array}$ & $\begin{array}{c}\text { Li-Ion VL45E } \\
\text { Cells, 7x1 } \\
\text { matrix, by Saft }\end{array}$ & $\begin{array}{c}\text { Total } \\
\text { Performance }\end{array}$ \\
\hline Capacity (Ah) & 125 & 45 & 170 \\
\hline Voltage (V) & 24 & 25.2 & 24 \\
\hline Weight (Kg) & $\begin{array}{c}\text { Unit 9.00Kg } \\
\text { Fuel 5.54Kg }\end{array}$ & 7.49 & 23.03 \\
\hline Total Energy (Wh) & 3,000 & 1,134 & 4,134 \\
\hline $\begin{array}{l}\text { Specific Energy } \\
\text { (Wh/Kg) }\end{array}$ & 206.33 & 151.4 & 179.38 \\
\hline $\begin{array}{l}\text { Energy Density } \\
\text { (Wh/ dm }{ }^{3} \text { ) }\end{array}$ & 105 & 313 & 237.1 \\
\hline $\begin{array}{l}\text { Specific Power } \\
\text { (W/Kg) }\end{array}$ & 17.19 & 664 & 133 \\
\hline $\begin{array}{l}\text { Power density } \\
\text { (W/dm }{ }^{3} \text { ) }\end{array}$ & 8.75 & 1392 & 18.3 \\
\hline Total Runtime (hr) & - & - & \\
\hline
\end{tabular}

An alternative solution is the $250 \mathrm{~W}$ DMFC by Idatech together with Li-Ion cells by Saft. Even though the available energy from the DMFC is directly proportional to the amount of fuel, its power limitations require the use of a second parallel energy storage unit. The proposed fuel cell and battery design, shown in Table IX, has the same weight as the proposed design of Table VIII and $21 \%$ higher runtime.

Finally, the high energy density DMFC and high power 
density Li-Ion design can be classified as a hybrid system similar to battery and super-capacitor hybrid systems. An active hybrid system would be proposed instead of a passive hybrid system. The introduction of a control system, DC/DC converter [27], eliminates all the negative effects of a passive hybrid system and gives more design flexibility. Furthermore, reference [28] has shown that a multilevel DC/DC converter can provide optimum fuel cell utilization.

\section{FURTHER DESIGN CONSIDERATIONS}

Several designs have been investigated including Lead Acid, Lithium and Fuel Cell Technologies. Lead Acid is the cheapest technology at a cost of approximately $\$ 320$ per KWh, the proposed Lithium technology from Saft, costs $\$ 2500$ per $\mathrm{KWh}$ whereas the proposed hybrid systems currently costs $\$ 3,104$ per KWh and is estimated to drop to $\$ 1893$ per KWh since the Idatech fuel cell is estimated to drop form $\$ 10,000$ to $\$ 5,000$ by the end of this year. The hybrid system is newer and as a result more expensive but at the same time it provides easy refueling and meets the power requirements without the need to over-size the batteries. Worth noting is that the projected cost for DMFC will drop to $\$ 200$ per KW [16] in which case the proposed hybrid design should drop to $\$ 696$ per KWh.

Additionally, when choosing any battery technology, care should be taken on operating temperatures and discharge currents. For choosing off the shelf products it is very important to identify the discharge rate and current of indicated capacity. An indicated capacity of $30 \mathrm{AH}$ at 20 hours discharge rate has a discharge current of only $1.5 \mathrm{~A}$, whereas for the same cell or battery pack, an increase of discharge current drops the capacity exponentially. As presented in figure 3 for the specific lead acid pack, discharge current follows a linear relationship with capacity of the order $y=33.8$ $0.78 x$ and an exponential relationship with discharge time or runtime of the order $y=27.86\left(e^{-0.21 x}\right)$.

\section{CONCLUSIONS}

This paper examined and identified reasons for the reduced UGV endurance, and in particular of a custom made $A T R V-J r$. As presented, the reasons were not only lead acid batteries but also excessive power demand that exponentially decreased the battery discharge time. Initial experimental analysis with comparative data suggested that for longer runtimes, it is first recommended to use lower power and more efficient sensors rather than over sizing the battery packs. Low power sensors, a Pentium mobile processor and a 90\% efficient power supply may decrease power consumption by $45 \%$. It has been shown that lithium ion technology meets the set energy requirements of $25 \mathrm{Km} / 12 \mathrm{hr}$ goal with only $15 \mathrm{Kg}$ whereas lead acid technology would require more than $72 \mathrm{Kg}$. Use of high energy cells such as VL45E and VL27M would provide the total mission energy demand with approximately one third less weight and volume. On the other hand, a combination of a
DMFC and Li-Ion has an energy density of $105 \mathrm{Wh} / \mathrm{dm}^{3}$ and offers runtime of $18.3 \mathrm{hrs}$. The proposed DMFC and Li-Ion solution offers a refueling time of just a few minutes whereas Li-Ion batteries alone need several hours. Therefore, for outdoor applications such as search and rescue, DMFC combined with Li-Ion cells are the most suitable design considering refueling time, weight, volume and runtime.

\section{REFERENCES}

[1] I. Yamamoto, T. Aoki, S. Tsukioka, H. Yoshida, T. Hyakudome, T. Sawa, S. Ishibashi, T. Inada, "Fuel Cell of AUV Urashima", Japan Agency for Marine-Earth Science and Technology, Mitsubishi Heavy Inductries, LTD, IEEE, 2004.

[2] G. Pappas, R. Rosenfeld, A. Beam, "The ARPA/Navy Unmanned Undersea Vehicle Program”, Unmanned Systems, Spring 1993, pp. 4144.

[3] K. E. Swider-Lyons, R. T. Carlin, R. L. Rosenfeld, R. J. Nowak, "Technical Issues and Opportunities for Fuel Cell Development for Autonomous Underwater Vehicles", IEEE, 2002.

[4] R. L. Rosenfeld, P. R. Prokopius, A. P. Meyer, "Fuel Cell Power System Development for Submersibles", IEEE Proceedings, Autonomous Underwater Vehicles Technology, IEEE AUV '92, 1992, pp. 184-188.

[5] Sandia National Laboratories, "Robotics Online - Fuel Cell Powered Mobile Robots Case Study", Online Posting. http://www.roboticsonline.com/public/articles/index.cfm?cat $=99$ (January 25, 2006).

[6] A. Wilhelm, J. Pharoah, B. Surgenor, "Fuel Cells and Mobile Robots, Fuel Cell Today, Online Posting. http://www.fuelcelltoday.com/FuelCellToday/IndustryInformation/Indus tryInformationExternal/IndustryInformationDisplayArticle/0,1588,933,0 0.html (January 25, 2006).

[7] K. Dalamagkidis, S. Ioannou, K. P. Valavanis, E. K. Stefanakos, “A Mobile Landing Platform for Miniature Vertical Take-Off and Landing Vehicles", to be published

[8] Isidor Buchmann, "Understanding Your Batteries in a Portable World", IEEE, 1999.

[9] Isidor Buchmann, "Batteries in Portable World", Second Edition, ISBN $0-9682118-2-8,2001$.

[10] EPCOS, Electronic Parts and Components, "General Technical Information - Ultracapacitor Technology", Online Posting. www.epcos.com/ultracapacitor.htm (October 5, 2005).

[11] Maxwell Technologies, "Ultracapacitor Application Notes",Online Posting. www.maxwell.com/ultracapacitors/support/ app_notes.html, (October 5, 2005).

[12] NESSCAP Technologies, "New Energy Systems - Electric Double Layer Capacitor", Online Posting, http://www.nesscap.com/prod/prod.htm (June 29, 2005).

[13] Skeleton Technologies Group, "Breakthrough in Supercapacitors", October 2003.

[14] Japan Storage Battery Co., Ltd., "Major Products - Lithium Ion", Online Posting. http://www.nippondenchi.co.jp/npd_e/lithium/ lithium.html (October 4, 2005).

[15] The University of Hong Kong and Friends of the Earth, "Feasibility Study of Renewable Hydrogen in Hong Kong", October 2004.

[16] C. C. Chan, "The State of the Art of Electric Vehicles", Department of Electrical and Electronic Engineering, University of Hong Kong, Journal of Asian Electric Vehicles, Volume 2, Number 2, December 2004.

[17] W. van Schalkwijk and B. Scrosati, "Advances in Lithium Ion Batteries, Chapter 16, Electrochemical Supercapacitors", Kluwer Academic/Plenum Publishers, 2002.

[18] B. E. Conway, "Electrochemical Supercapacitors: Scientific Fundamentals and Technological Applications", New York: Plenum, 1999.

[19] G. L Bullard, H. B. Sierra-Alcazar, H. L. Lee, J. L. Morris, "Operating Principles of Ultracapacitor", IEEE, January 1989.

[20] Ilya Gavrichenkov, Xbit Labratories, "CPU Category - Intel Pentium D 820 CPU Review, Page 3, 05/27/2005”, Online Posting. 
http://www.xbitlabs.com/articles/cpu/display/pentiumd-820 $3 . \mathrm{html}$, (January 21, 2006).

[21] Intel United States, "Processors - Mobile Intel Pentium 4 Processors M, Voltage Requirements", Online Posting. http://www.intel.com/support/processors/mobile/pentium4/sb/cs007501.htm, (January 21, 2005).

[22] Intel United States, "Processors - Mobile Intel Pentium 4 Processors M, Enhanced Intel SpeedStep ${ }^{\circledR}$ Technology”, Online Posting. http://www.intel.com/support/processors/mobile/pentium4/sb/cs007499.htm, (January 21, 2005).

[23] Walter A. Van Schalkwijk, "Lithium Rechargable Batteries".

[24] M. Broussely, M. Perelle, J. McDowal and G. Sarre, "Lithium Ion: The next Generation of Long Life Batteries - Characteristics, Life Predictions and Integration into Telecom Systems", IEEE, 2000.
[25] Ballard, "Fuel Cell Products- Mark 902 Transportation Fuel Cell Module", Online Posting. http://www.ballard.com/be_a_customer/ transportation/fuel cell modules/mark 902 (October 5, 2005).

[26] Hydrogenics Corporation, "H2X Fuel Cell Stack Specifications”, Online Posting. http://www.hydrogenics.com/products stacks fc products.asp (October 5, 2005).

[27] R. A. Dougal, S, Liu and R. E. White, "Power and Life Extension of Battery-Ultracapacitor hybrids", IEEE, March 2002.

[28] B. Ozpineci, L. M. Tolbert, G. Su, Z. Du, "Optimum Fuel Cell Utilization with Multilevel DC/DC Converters", Oak Ridge National Laboratory and Department of Electrical and Computer Engineering, IEEE, 2004

TABLE IV

SUPER-CAPACITOR TECHNOLOGY PROFILE (FROM [10] - [13])

\begin{tabular}{|c|c|c|c|c|c|c|c|c|}
\hline \multirow[t]{2}{*}{ Brand } & \multirow{2}{*}{$\begin{array}{c}\text { Voltage } \\
\text { Volt } \\
\end{array}$} & \multirow{2}{*}{$\begin{array}{c}\text { Capacitance } \\
\text { Farads } \\
\end{array}$} & \multicolumn{2}{|c|}{$\operatorname{ESR}(\mathrm{m} \Omega)$} & \multirow{2}{*}{$\begin{array}{l}\text { Energy } \\
\text { Wh/Kg } \\
\end{array}$} & \multirow{2}{*}{$\begin{array}{l}\text { Power } \\
\text { W/Kg }\end{array}$} & \multirow{2}{*}{$\begin{array}{c}\text { Weight } \\
\text { Gr. }\end{array}$} & \multirow{2}{*}{$\begin{array}{c}\text { RC time constant } \\
\text { Sec }\end{array}$} \\
\hline & & & DC & $\mathbf{A C}$ & & & & \\
\hline \multicolumn{9}{|l|}{ Single Cell } \\
\hline EPCOS & 2.5 & 1800 & 0.6 & 0.3 & 2.9 & 2300 & 540 & 1.08 \\
\hline NESS & 2.3 & 20 & 55 & 40 & 3.7 & 6600 & 4 & 1.10 \\
\hline Maxwell & 2.7 & 2600 & 0.4 & 0.28 & 5.6 & 10400 & 470 & 1.04 \\
\hline Skeleton & 3 & 47 & 5.5 & - & 11.5 & 9600 & 5 & 0.26 \\
\hline \multicolumn{9}{|l|}{ MODULES } \\
\hline EPCOS & 14 & 200 & 5 & 2.6 & 1.9 & 1700 & 2800 & 2.50 \\
\hline EPCOS & 42 & 67 & 15 & 8 & 2 & 1700 & 8200 & 1.01 \\
\hline NESS & 5.4 & 1.5 & 200 & 150 & 1.74 & 10410 & 3.5 & 0.30 \\
\hline Maxwell & 16.2 & 430 & 3.5 & 2.5 & 3.1 & 5200 & 5000 & 1.51 \\
\hline
\end{tabular}

TABLE VIII

COMPARISON OF LEAD ACID AND LI-ION BATTERY COMBINATIONS

\begin{tabular}{|c|c|c|c|c|c|}
\hline \multirow[b]{2}{*}{ Type } & \multirow{2}{*}{$\begin{array}{c}\text { Current } \\
\text { DCS-33 Lead Acid }\end{array}$} & \multicolumn{4}{|c|}{ Alternatives } \\
\hline & & $\begin{array}{l}\text { Li-Ion VL20P Cells, } \\
7 \times 4 \text { matrix, by Saft }\end{array}$ & $\begin{array}{c}\text { Li-Ion VL27M } \\
\text { Cells, 7x3 matrix, by } \\
\text { Saft }\end{array}$ & $\begin{array}{l}\text { Li-Ion VL30P Cells, } \\
7 \times 3 \text { matrix, by Saft }\end{array}$ & $\begin{array}{l}\text { Li-Ion VL45E Cells, } \\
7 \times 2 \text { matrix, by Saft }\end{array}$ \\
\hline Capacity (Ah) & 26 at $\mathrm{C} / 3$ & 80 at $1 \mathrm{C}$ & 81 at $\mathrm{C} / 3$ & 90 at $1 \mathrm{C}$ & 90 at $\mathrm{C} / 3$ \\
\hline Voltage (V) & 24 & 25.2 & 25.2 & 25.2 & 25.2 \\
\hline Weight (Kg) & 24 & 22.4 & 16.17 & 23.1 & 15 \\
\hline Total Energy (Wh) & 624 & 2016 & 2041 & 2268 & 2268 \\
\hline Specific Energy (Wh/Kg) & 26 & 90 & 126.23 & 98.2 & 151.4 \\
\hline Energy Density $\left(\mathrm{Wh} / \mathrm{dm}^{3}\right)$ & 78.6 & 187 & 252 & 209 & 313 \\
\hline Specific Power (W/Kg) & 208 & 1413 & 987 & 1136 & 664 \\
\hline Power Density $\left(\mathrm{W} / \mathbf{d m}^{3}\right)$ & 604 & 2974 & 2000 & 2451 & 1392 \\
\hline Total Runtime (Hrs) & 2.7 & 8.92 & 9.03 & 10.0 & 10.0 \\
\hline
\end{tabular}

